\title{
Canadian Constitutional Law: Presentation to the Annual Conference of International Association of Law Libraries
}

Peter W. Hogg

Osgoode Hall Law School of York University

\section{Source Publication:}

International Journal of Legal Information. Volume 41, Issue 1 (2013), p. 58-64.

Follow this and additional works at: https://digitalcommons.osgoode.yorku.ca/scholarly_works (c) (i) $(9)$

This work is licensed under a Creative Commons Attribution-Noncommercial-No Derivative Works 4.0 License.

\section{Recommended Citation}

Hogg, Peter W. "Canadian Constitutional Law: Presentation to the Annual Conference of International Association of Law Libraries." International Journal of Legal Information 41.1 (2013): 58-64.

This Article is brought to you for free and open access by the Faculty Scholarship at Osgoode Digital Commons. It has been accepted for inclusion in Articles \& Book Chapters by an authorized administrator of Osgoode Digital Commons. 


\title{
Canadian Constitutional Law: Presentation to the Annual Conference of International Association of Law Libraries
}

\author{
PETER W. HOGG*
}

\section{Introduction}

When I was asked to give this talk it occurred to me that it might be interesting to think aloud about some of the changes in constitutional lawand in writing about constitutional law--that have occurred since I came to Canada. I am a New Zealander by birth, but I was teaching at the Faculty of Law of Monash University in Melbourne, Australia, when I came to the Osgoode Hall Law School on a one-year visit in the summer of 1970. During that visiting year, the faculty decided to offer me a permanent appointment. This was done over the objection of one of my colleagues, R. J. Gray, who claimed that my lectures would require simultaneous translation, and that I would not meet the height requirements for Canadian citizenship. Anyway I was persuaded to stay (and three years later I became a Canadian citizen).

The then Dean, Gerald LeDain, in giving me my teaching assignments for the next year, which was 1971-72, asked me to teach Canadian constitutional law. I objected that I knew nothing about Canadian constitutional law. He brushed that aside. He explained that he only had four teachers for the five sections of first-year constitutional law. So I started teaching constitutional law.

\section{Constitutional Law Before the Charter of Rights}

Canada is a federal country with its capital in Ottawa and it now comprises ten provinces and three territories. Its constitution is the Constitution Act, 1867, formerly the British North America Act, 1867, which is a statute of the United Kingdom Parliament at Westminster, which had authority to legislate for British colonies. A united Canada had to be a federal

* Peter W. Hogg, C.C., Q.C., Professor Emeritus, Osgoode Hall Law School, York University; Scholar in Residence, Blake, Cassels \& Graydon LLP, Toronto. 
country because of its huge size and the diversity of its regions, but especially because of the fact that its French-speaking population is concentrated in Quebec, which has always been very protective of its French language and culture on a continent where English is the dominant language. The

Constitution Act, 1867 divides legislative authority between the Parliament of Canada in Ottawa and the Legislatures of the ten provinces. Disputes about the extent of the legislative authority of each of the two levels of government are frequent, and are adjudicated by the courts and ultimately the Supreme Court of Canada.'

When I started teaching constitutional law in Canada in 1971, there were two casebooks on constitutional law, one by Bora Laskin ${ }^{2}$ and the other by Noel Lyon and Ron Atkey. ${ }^{3}$ Ron Atkey also joined the Osgoode Hall Law School faculty in 1971 and he used the Lyon and Atkey book, as did Irwin Cotler, as I recall. The rest of us used the Laskin casebook, which was a great work of scholarship, but very difficult for first-year students. The only textbook that could conceivably be regarded as current was F.P. Varcoe, The Constitution of Canada (2nd ed. 1965), but this was a short work that was far from comprehensive. For more ambitious works you had to go back to Clement, $3^{\text {rd }}$ ed. $1916,{ }^{4}$ Lefroy, $1918,{ }^{5}$ Riddell, $1923^{6}$ and Kennedy, 2nd edition, $1938^{7}$--all works that were so out of date that they did not even conceive the subject in recognizable modern terms.

One of the difficulties with the Laskin casebook for me was that it was exclusively devoted to federalism. Laskin, like the other great academic constitutional lawyers of his time, Frank Scott, Bill Lederman and Vincent MacDonald, for example, was preoccupied with the political issues of federalism and with judicial review of the federal distribution of powers. Federalism was the dominating constitutional issue, and had been for many

' The final decision-maker used to be the Privy Council in London, but the authority of the Privy Council was terminated in 1949.

${ }^{2}$ B. Laskin, Canadian Constitutional Law (Carswell, Toronto, 3rd ed. 1969 by Laskin, $4^{\text {th }}$ ed. 1975 by Abel, $5^{\text {th }}$ ed. 1986 by Finkelstein).

${ }^{3}$ J.N. Lyon and R.G. Atkey, Canadian Constitutional Law in a Modern Perspective (U. Toronto Press, 1970). 1916).

${ }^{4}$ W.H.P. Clement, The Law of the Canadian Constitution (Carswell, $3^{\text {rd }}$ ed.,

${ }^{5}$ A.H.F. Lefroy, Canadian Constitutional Law (Carswell, 1918). 1923).

${ }^{6}$ W.R. Riddell, The Canadian Constitution in Form and Fact (Columbia U. P.,

${ }^{7}$ W.P.M. Kennedy, The Constitution of Canada 1534-1937 (Oxford U.P., $2^{\text {nd }}$ ed., 1938). 
years. There was nothing in the Laskin casebook on the sources of Canadian constitutional law, on the evolution from colony to independent country, on responsible government, on the Crown, or on civil liberties, for example. I was interested in these kinds of things - constitutional ideas that Canada shared with New Zealand and Australia. So I started producing notes for the students to supplement the casebook. Of course, I quickly became interested in Canadian federalism as well, and gradually learned something about it, especially from the writings of Laskin and Lederman. Then, as I came up to my first sabbatical leave in 1976-77, it occurred to me for the first time that I had the basis for a text on constitutional law, and in the course of a year spent on leave at the University of Toronto I expanded the student notes into a textbook. That was the origin of my book on Constitutional Law of Canada, the first edition of which was published in $1977 .^{8}$

\section{The Charter of Rights}

The Constitution Act, 1867 did not contain a bill of rights on the American model. There were some guarantees of language and religion rights, which were preoccupations in 1867, but the Canadian framers of confederation looked to the United Kingdom for their inspiration, not the United States, and the British view at that time was that human rights were best safeguarded without a constitutional bill of rights. And it is true that, even in countries that have bills of rights, the most important protections of human rights come from democracy, the rule of law, the independence of the judiciary, and the independence of the bar. However, after the Second World War, it became widely accepted that a constitutional bill of rights was an indispensable addition to the suite of safeguards that were exemplified by the legal system of the United Kingdom. All of the British colonies that achieved independence after the War insisted on having bills of rights in their constitutions-which were duly drafted in the United Kingdom by British constitutional lawyers! Canada adopted a statutory bill of rights in 1960, the Canadian Bill of Rights, but because it did not have constitutional force it did not have much effect. However, in 1982, by virtue of the driving force of Prime Minister Pierre Trudeau, Canada adopted the Charter of Rights, which is contained in the Constitution Act, 1982, another statute of the United Kingdom Parliament which, like the Constitution Act, 1867, does have

\footnotetext{
${ }^{8}$ P.W. Hogg, Constitutional Law of Canada (Carswell, 1977, $2^{\text {nd }}$ ed., 1985, $3^{\text {rd }}$ ed., $1992,4^{\text {th }}$ ed., 1997, 5th ed., 2007, now also in loose-leaf format annually supplemented).
} 
constitutional force; it is supreme over ordinary federal and provincial statutes. ${ }^{9}$

After the adoption of the Charter of Rights in 1982, everything changed in the world of Canadian constitutional law. Suddenly, the Dean's problems in staffing constitutional law were over. Everyone on the faculty of the Osgoode Hall Law School (and the other law faculties in Canada) wanted to teach constitutional law. Everyone who applied for an academic appointment wanted to teach constitutional law.

The Canadian courts were deluged with constitutional cases. The volume of cases was truly disturbing. A study of s. 15 (the equality guarantee) by Gwen Brodsky and Sheila Day in 1989 found that, in the first three years of s. 15 (which came into force in 1985, three years after the rest of the Charter) there were 590 cases (of which two-thirds were reported) in which the validity of a law was attacked under s. $15 .^{10}$ And that was just the equality guarantee! The flood of cases was matched by a comparable flood of academic writing. Canadian law schools were now well staffed with faculty, and a remarkable number of them had become instant constitutional lawyers. ${ }^{11}$

It took a few years for the flood of Charter cases to find its way to the Supreme Court of Canada, but the Court took to its new task of judicial review with enthusiasm. It became a more "activist" court than the Supreme Court of the United States, even more so than the Warren Court of the 1960s. Hamar Foster and an American co-author published a study showing that those Charter guarantees that had counterparts in the American Bill of Rights were for the most part given wider interpretations than the American court had provided. ${ }^{12}$ More statutes were struck down here than in the United

${ }^{9}$ The embarrassment of having to get constitutional instruments enacted in the United Kingdom was also eliminated in 1982 when amending procedures were adopted that could be operated within Canada and the U.K. Parliament terminated its authority over Canada. The story is told in Hogg, note 7, above, ch. 3.

${ }^{10}$ Brodsky and Day, Canadian Charter Rights for Women (1989).

${ }^{11}$ As I write in 2012, globalization has for the time being supplanted constitutional law as the academic lawyer's pursuit of choice.

${ }^{12}$ R. Harvie and H. Foster, "Ties that Bind? The Supreme Court of Canada, American Jurisprudence, and the Revision of Canadian Criminal Law under the Charter" (1990) 28 Osgoode Hall L.J. 729; R. Harvie and H. Foster, "Different Drummers, Different Drums: The Supreme Court of Canada, American Jurisprudence and the Continuing Revision of Canadian Criminal Law under the Charter" (1992) 24 Ottawa L. Rev. 39. 
States. Aggressive remedies for unconstitutional laws became commonplace. These included the severance of words from a statute in order to alter the meaning intended by the legislature and the "reading in" (that is the addition) of new words to a statute that the legislature had never enacted. And procedural restraints developed by the American court (Alexander Bickel's "passive virtues") through such doctrines as standing, ripeness, mootness, hypothetical questions and political questions were often disregarded or rejected. ${ }^{13}$

All this had a great effect on my textbook, the first edition of which had been published in 1977 and had taken up 500 pages. It went into a second edition in 1984, and jumped to 1,000 pages. The third edition jumped to 1,500 pages. The fourth edition was longer still. The fifth edition, completed in 2007, is just under 2,000 pages and is in two volumes. It is now in looseleaf version as well as conventional bound volumes, and preparing the annual supplement to keep the book up to date occupies an important part of my working time all year. Oddly enough, it is still the only comprehensive textbook on the constitutional law of Canada. Of course, our market is only one tenth the size of that of the United States, and there are only a few comprehensive texts there.

\section{The Legitimacy of Judicial Review}

After the adoption of the Charter of Rights in 1982, the increased role of the courts in the formation of Canada's public policy naturally led to debate about the legitimacy of judicial review, just as the Warren Court had sparked a similar debate in the United States. Unsurprisingly, abortion, pornography, women's rights, gay and lesbian rights and the rights of criminal defendants were among the issues that attracted public attention. In the law reviews, the legitimacy debate was quite sophisticated, building as it did on the immense and subtle literature accumulated in the United States.

What was lacking in the legitimacy debate in Canada was any empirical evidence of the actual impact of judicial review on the law-making process in Canada. In an article published in 1997, ${ }^{14}$ Allison Bushell (now Thornton) and I investigated the sequels to all cases in which the Supreme Court of Canada had struck down a law on Charter grounds. What we found

${ }^{13}$ P.W. Hogg, "The Law-Making Role of the Supreme Court of Canada" (2001) 80 Can. Bar Rev. 173.

${ }^{14}$ P.W. Hogg and A. Bushell, "The Charter Dialogue between Courts and Legislatures" (1997) 35 Osgoode Hall L.J. 76. 
was rather surprising. Out of 66 cases in which laws had been struck down on Charter grounds, more than two-thirds of the cases were followed by the enactment of a new law that continued to carry out the policy of the old, invalid law. Most of the time, the Court did not have the last word!

There were a number of reasons for the ability of Canadian legislative bodies to take a second look at legislation that had been struck down by the Court. One was the presence in the Charter of Rights of an override clause (s. 33), which enabled Parliament or the Legislature to override the Charter of Rights by inserting a "notwithstanding clause" in legislation. This has been rarely used, because it constitutes an acknowledgment that the legislative body is legislating in violation of the Charter, but when it is used it allows the legislation to overcome a Charter decision. The second, and more important, provision was s. 1 of the Charter, which makes the Charter subject to "such reasonable limits prescribed by law as can be demonstrably justified in a free and democratic society". Section 1 allows a legislative body to overcome a Charter decision by making changes to the invalid law to satisfy the Court's jurisprudence on "reasonable limits". Neither of these loopholes exists in the American Bill of Rights. And what Allison's and my article showed was that our Charter led to a weaker form of judicial review than the strong form assumed to be characteristic of the United States. Allison and I argued that judicial review in Canada should be regarded not as imposing a veto on democratic legislatures, but as contributing to a "dialogue" between the Court and the legislatures.

Our 1997 dialogue article led to a "dialogue on dialogue" as the Supreme Court of Canada picked up the idea and gave it some unexpected twists, and many commentators weighed in, either criticizing or elaborating on the thesis. In 2007 (with the help of a third co-author, Wade Wright), we published a sequel article that attempted to review the decisions and the academic literature that had talked about the 1997 article. $^{15}$ In the 2007 article, we also researched the legislative sequels to all the Charter cases since 1997, and we found that the same pattern had continued: a decision striking down a law on Charter grounds was usually followed by a new law that accomplished the same legislative objective. The "dialogue" that we had identified in 1997 was still alive and well in 2007.

${ }^{15}$ P.W. Hogg, A.A. Bushell Thornton, W.K. Wright, "Charter Dialogue Revisited-Or Much Ado about Metaphors" (2007) 45 Osgoode Hall L.J. 1. 


\section{Conclusion}

The important point, I think, is this: Canada has a unique constitutional history, and its constitutional documents are naturally unique too. The text of the division of powers (federalism) was influenced by the American Constitution (the only useful federal precedent in 1867), but departed markedly from it to respond to the political exigencies and ideas of the Canadian colonists. The text of the Charter of Rights was influenced by the American Bill of Rights, but was also influenced by international human rights instruments (the source of s. 1) and by purely Canadian ideas (such as s. 33). The Supreme Court of Canada has developed, and continues to develop, a distinctively Canadian exegesis of these instruments. The academic commentary on the Canadian constitution is also distinctively Canadian, drawing on British roots, and influenced by American political and legal literature, to be sure, but ultimately about the governance structure of Canada, a country like no other. 